縎死未遂にて生じた喉頭狭窄の 1 例

大黒 慎二・朝倉 光司・齋藤 博子

渡辺 雅子・形浦 昭克

\title{
Chronic Laryngeal Stenosis due to Suicide Attempt
}

\author{
Shinji Ohguro, Kohji Asakura, Hiroko Saito, \\ Masako Watanabe and Akikatsu Kataura \\ (Sapporo Medical University)
}

\begin{abstract}
We present a patient with chronic stenosis of the larynx due to attempted suicide by hanging. A 32-year-old male with schizophrenia attempted to hang himself. He consulted our hospital with a complaint of difficulty in swallowing. Fiberscopic examination and CT findings revealed blunt damage between the hyoid bone and thyroid cartilage.

Resection of scar was done to maintain a sufficient lumen. After surgery, his swallowing improved.

It would be better to evaluate the larynx as soon as possible when examining a patient with neck injury.
\end{abstract}

Key words : stenosis of the larynx, suicide, neck injury

はじめに

喉頭外傷は，前頸部に加わった鈍的あるいは鋭的外傷 により生じ，それにより呼吸や讌下などの障害が引き起 こされる. 喉頭は本来下買, 鎖骨, 胸骨扣よび頸椎に囲 まれており，外傷を受けにくい器官とされている。しか しながら近年の交通事故の多発と，一方では救急救命技 術の向上により本疾患は増加しつつあるとも言われてい る。

急性期においてはもちろん気道外傷であることが最も 重要であり, 気道確保を含む初期治療が大切である. たしばしば特に閉鎖性の損傷では急性期に見逃されるこ とによって, 後になって瘢痕性の狭窄による呼吸困難や 誤曣などの症状を呈し，その治療に難橴することがある。

今回我々は自殺企図によって首吊りといら特異な受傷 機転の後, 喉頭狭窄をきたした 1 症例を経験したので, 若干の文献的考察を加えて報告する.
症例

症例 : 32歳, 男性.

既往歴: 20 歳代より精神分裂病を発症し, 治療中であ る.

現病歷: 平成 3 年 12 月 25 日に妄想打よび幻覚などの異 常体験をきっかけとして首吊りにより自殺を図った，発 見後すぐに頸椎の骨折の疑いで，近医脳神経外科の救急 外来に搬入され救急救命措置を受けた. 受傷後流動食に よる経口摂取を行っていたが，徐々に與下障害が進行す るために当科に紹介となった。

初診時所見：発声はくぐもった声であり，声門上の狭 窄が疑われたが明らかな呼吸障害はなかった。燕下は流 動状でなければ行えず，また䛊曣をともなっていた。喉 頭ファイバー所見では声門上に直径が約 $10 \mathrm{~mm}$ の咽, 喉頭の全周性の狭窄があり，この狭窄を越えないと声門 部が充分に観察できなかった(図 1). 頸部の単純 X線の 所見では，舌骨のやや下方での著明な狭窄と喉頭 (甲状 


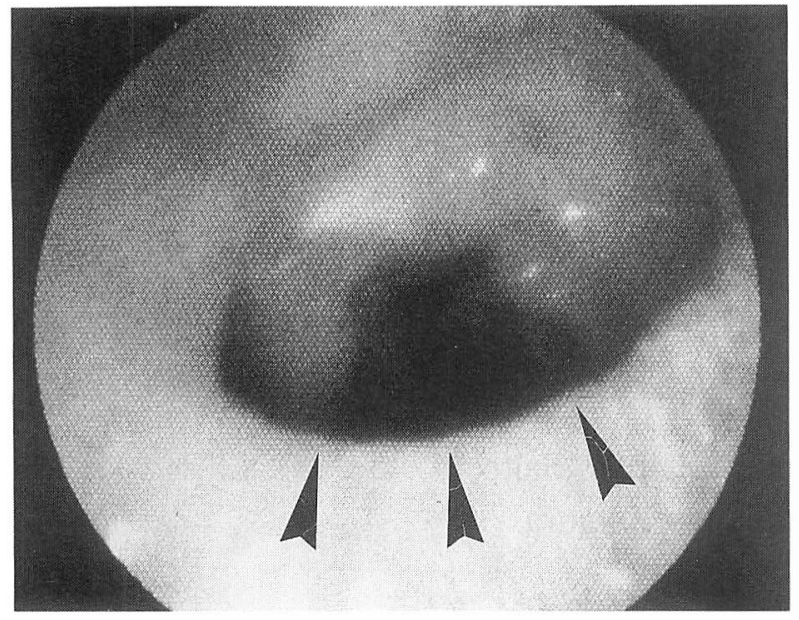

図 1 術前の喉頭フォイバー所見 声門上の狭窄 (知印)を認める.

軟骨)の著明な下方変位の所見が認められた(図 2 )。さ らにバリウムの透視所見では，狭窄部に一致した著明な 通過障害, 喉頭蓋の固着, これらによる over-flow mis-swallowing を示していた. 3 次元 CTにて骨, 軟骨の状態 を立体的にみると，舌骨と甲状軟骨の間が異常に広がっ ていた(図 3 )。これらの所見から，首吊りの際に舌骨と

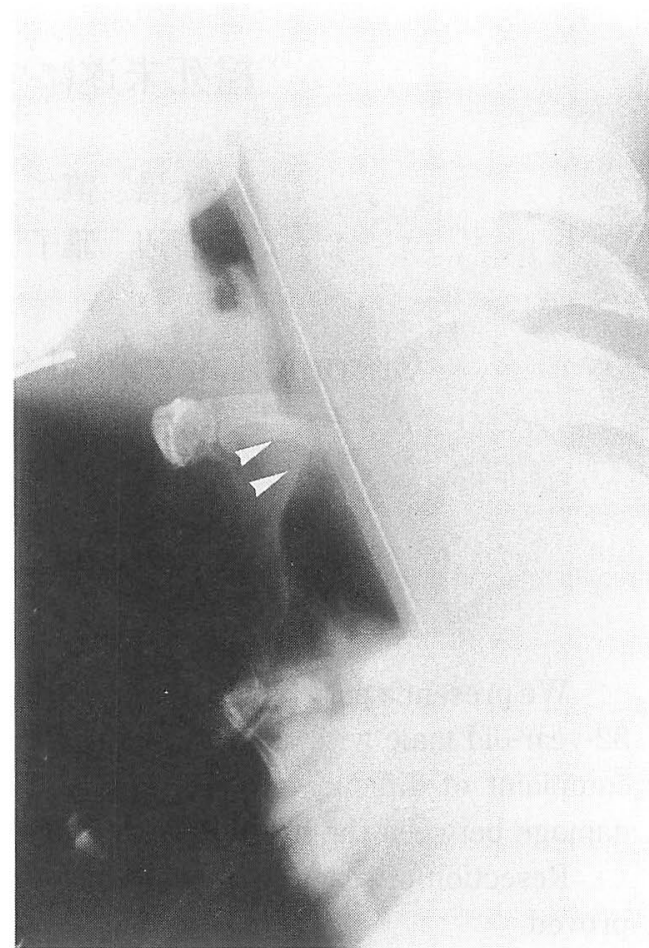

図 2 術前のX線頸部側面像 舌骨の下方に狭窄(矢印)が認められる.

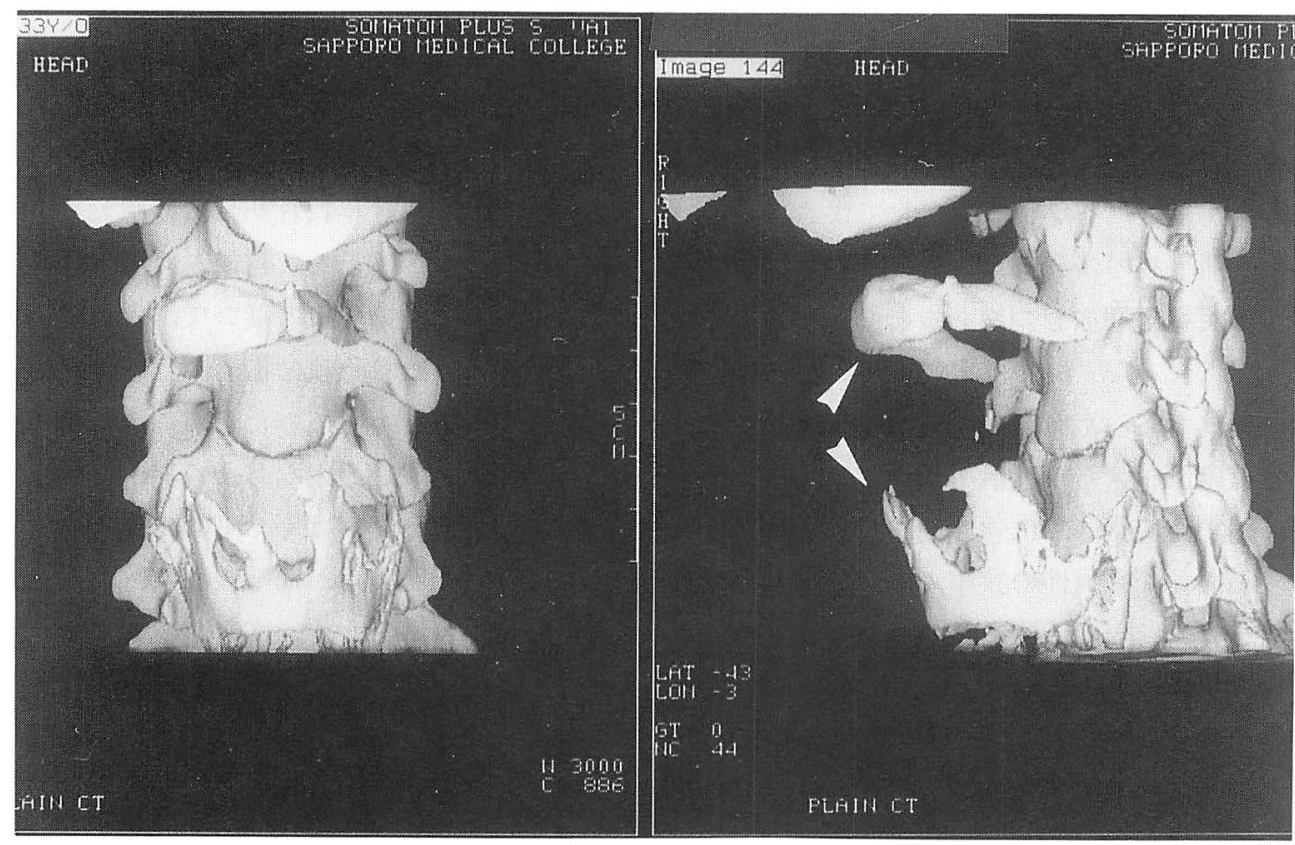

図 33 次元 CT 所見

舌骨と甲状軟骨の間が異常に広がっている(矢印)。骨折は認めない。 
甲状軟骨の間に外力が加わった結果, 強く伸展され, 粘 膜や勒帯などに損傷を受けたために後になって媻痕狭窄 をきたしたものと考兄られたため，平成 4 年 9 月 24 日に 洀痕の除去術を行った。

術中所見（図 4)：前頸部に横切開を加光，舌骨の下面 に沿って軟部組織を剥離し咽頭内腔に達した，狭窄は全 周性であったが，痗痕は前壁の久であった，後壁は損傷 されて扣らず，前方の狭窄によって牽引されていたもの と考光られた。症痕を除去した後，内腔を広げるために 粘膜を上下に合わせるように縫合した。

術後のファイバー所見では瘢痕は若干残ってはいるも のの，声門部は充分に観察が可能であり狭窄は改善され ていた(図 5 ). 頸部食道バリウム所見でも狭窄が除去さ れて内腔の広がっている所見が得られた(図 6 )。また実 際の讌下の際には，喉頭蓋が舌面で癒着しているために 動きが悪く, 多少の誤燕はあるものの経口摂取は可能と なり音声も改善し，現在外来観察中である.

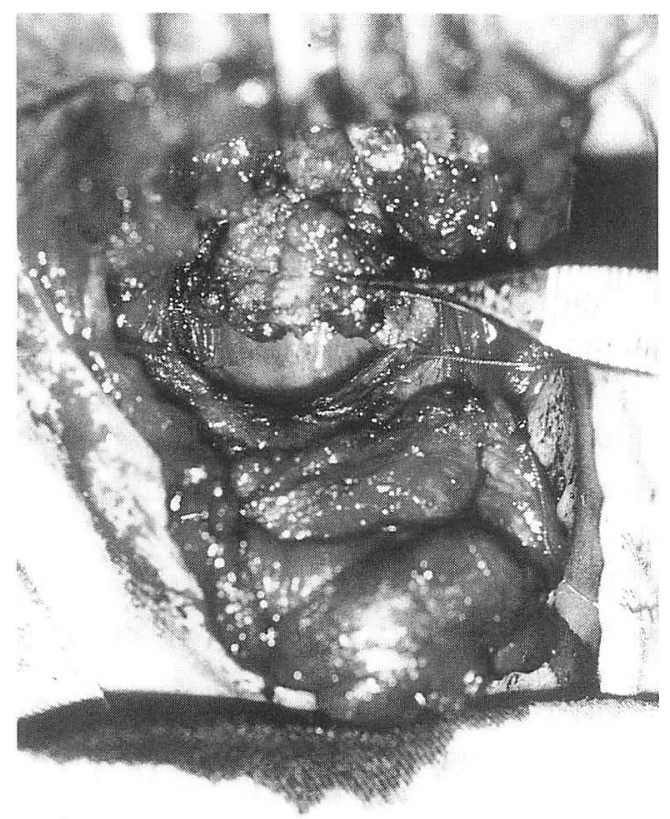

図 4 術中所見 鑷子で把持しているのが㗪痕である。

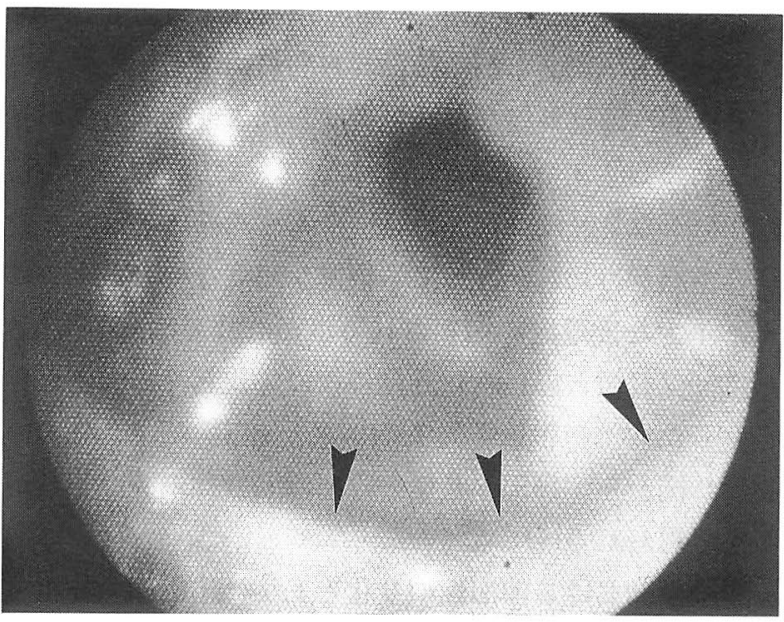

図 5 術後の喉頭ファイバー所見 狭窄は改善し(矢印)声門全体の観察が可能である.

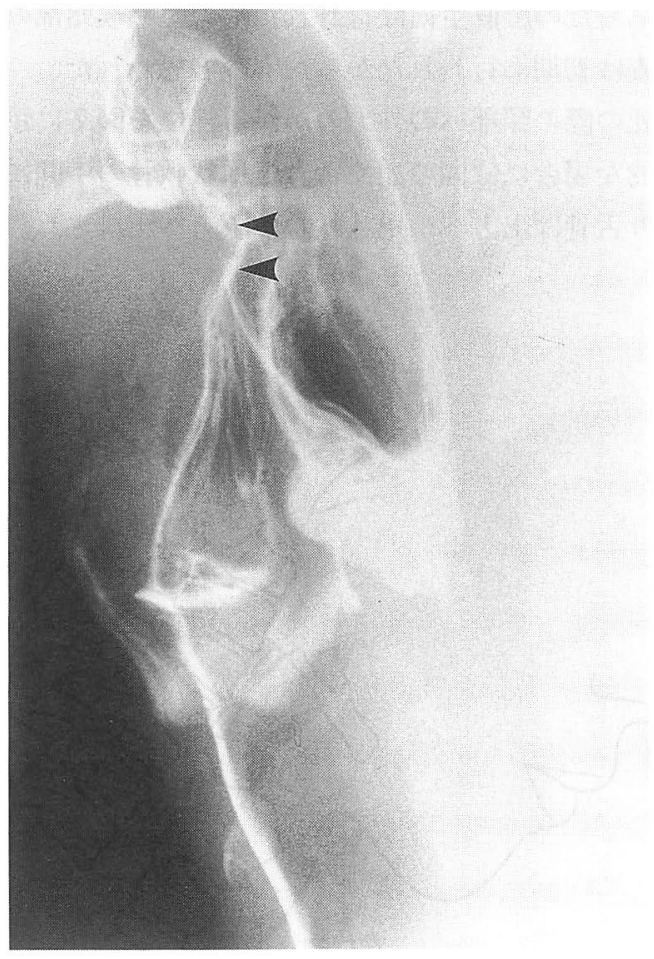

図 6 術後の頸部食道バリウム所見 術前に比べて狭窄は改善されている(矢印).

\section{考察}

喉頭外傷の原因には交通事故, 労働災害, スポーツ, 医原性（気管切開，気管内挿管など)。薬物，自殺未遂な 
ど様々なものがある1)。近年増加している交通事故の際 には特にそらであるが，頸部の単独の損傷でない場合に はしばしば頭部外傷などに目を奪われて，喉頭外傷が見 逃されてしまらことがまれではない。この様に充分な初 期治療がなされていない場合にはもちろんであるが, 適 切な治療が行われたとしても損傷が高度な場合などでは 後に重大な後遺症に悩まされる事がしばしばある2).さ らに一見軽微と思われた外傷の後に, 重篤な呼吸困難を きたした症例の報告もある3)ので，受傷機転や，外力の 程度に関わらず頸部の外傷の際には咽喉頭内腔の観察が 必須と思われる.

慢性期に㨟ける陳旧性の変化としては，喉頭の枠組み の変形, 粘膜肥厚, 肉芽形成, 瘢痕形成, 声門癒着, 声 門の変形，運動障害などがあり，これらによって様々な 程度の呼吸困難, 嗄声などが起こりらる. 本症例の場合 には，受傷機転が繿死未遂と特殊であり，閉鎖性の損傷 でもあったので蘇生術は行われたものの咽喉頭部の観察 や精査は初期に行われなかったものと思われた.

緼死の際の頸部への外力のかかる部位を図 7 に示す. 定型的な場合には図の如く舌骨と甲状軟骨の中間に力が 加わり舌骨は上方へ，甲状軟骨は下方へ圧排され，これ

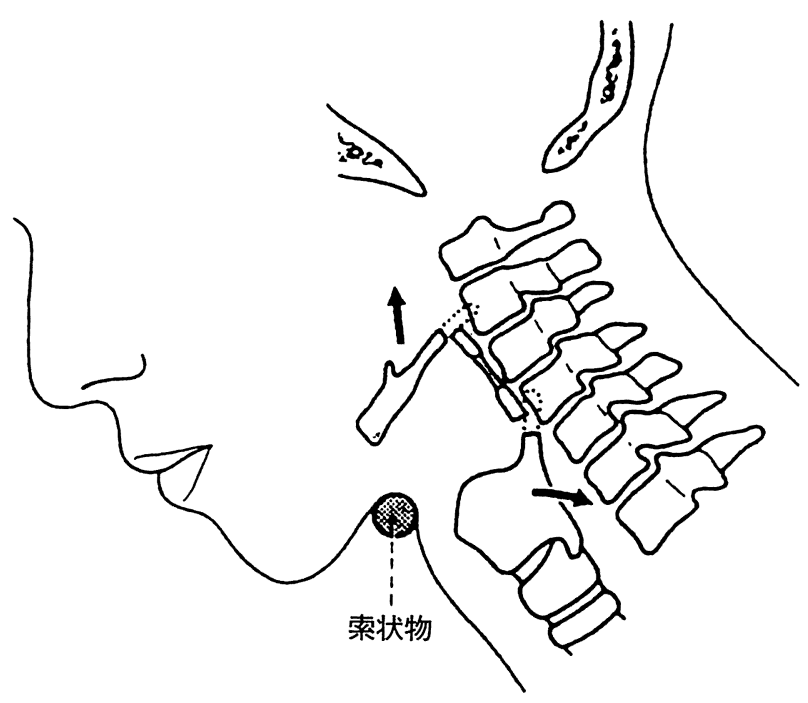

図 7 外力が加わり, 舌骨は上方へ, また甲状軟骨は下方へ圧 排される(文献 4 ) より改変)
は本症例の所見と全く一致している. また時に舌骨の大 角や甲状軟骨の上角に骨折を認めることがあるとされて いる一方, 甲状軟骨の板や輪状軟骨の骨折はほとんどな く, 通常外力のかかった部位の組織の挫隇や出血が生じ る4). 今回の症例では骨折は認めていないが，甲状喉頭 蓋勒帯, 舌骨甲状勒帯の断裂が生じ, これが後になって 瘢痕となり狭窄をさたしたと推測された。

陳旧性の症痕の治療法であるが，これには難渋するこ とが多いよらである.一定の方法と言うものはないが, 基本的な考光方として, 瘢痕の除去, 整復, 粘膜の温存 が重要であり，必要に応じてステントもしばしば用いら れる5). 我々の症例では, 舌骨と甲状軟骨の間の組織の 挫滅にともなら症痕のみであったのでこの切除を行った。 しかしながら喉頭蓋舌面の癒着があるため, 若干の機能 障害は残っている.

\section{まとめ}

緼死未遂といら特殊な受傷機転により生じた喉頭外傷 に 1 例を経験した.

頸部への外力が加わったと考兄られた際には, 受傷機 転や外力の程度に関わらず，速やかに喉頭内の精査およ び加療を行らことが重要と考えられた.

\section{参考文献}

1 ) 小林武夫, 岡部和也, 村上 泰, 他 : 喉頭外傷. JOHNS $3: 749 \sim 756,1987$.

2）佐藤武男：喉頭狭窄の病態と治療. 日気食会報 $30: 120$ $122,1979$.

3 ) 武本欣也, 設楽哲也 : 稀有な喉頭外傷.耳鼻 $17: 168 \sim 174$, 1971.

4 ) 冨田功一, 古屋義人, 石津日出雄, 他 : 緼死. 標準法医学 - 医事法 一第 3 版一(冨田功一, 上山滋太郎編). 137 140頁, 医学書院, 東京, 1989.

5 ）小宮山荘太郎：外傷性慢性喉頭・気管狭窄。日気食会報 $41: 348 \sim 352,1990$.

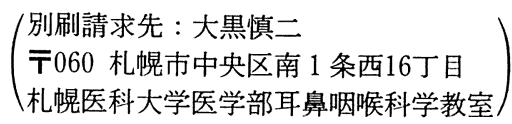

